his opening remarks, Lord Citrine anticipated a fiveyear shortage of electrical plant in spite of the fact that the manufacturers are attempting to double their 1938 output. Consequently, with electric power demands already 60 per cent above the 1938 level, and the effects of the war-time lag in extensions and maintenance still to be caught up, there are bound to be power cuts in this and succeeding winters unless the domestic consumer is much more careful. In the exhibition this point is brought home by a series of working models. Thus, by pressing a button the visitor brings on an electric fire but at the same time stops the operation of a model workshop. The workers sit down to wait until the fire is switched off again. An illuminated label at the same time stresses the need to avoid the peak load hours of 8-10 a.m. and 4-6 p.m. The loads taken by various domestic gas and electric appliances are shown by a colourful series of panels, which also suggest how to make reasonable savings without undue austerity.

\section{American Institute of Physics}

Mr. Cleverland Norcross, formerly executive secretary of the Office of Scientific Research and Development, the official organisation which coordinated American scientific work during the War, has been appointed to the newly created post of assistant director of the American Institute of Physics ; Dr. H. A. Barton continues as director of the Institute. The administrative change has been necessitated by the enormous increase in the administrative burdens of the Institute, largely due to the continued increase in the number of physicists (the number has trebled in the past ten years, but which is by no means sufficient yet to meet the demands of industry, government research and teaching establishments), and to the growing recognition by the general public of the part that physics does and should play in industrial and national progress. The director will continue to be responsible to the governing board for the general supervision of the Institute, but will be primarily responsible for matters of policy and relations between physical organisations and allied bodies. Advertisement, appointments, public relations, and attention to matters affecting the member societies of the Institute will be the main concern of the assistant director.

\section{International Scientific Film Association}

At a congress in Paris during October 2-9, arranged jointly by the Institut de Cinématographie Scientifique and the Scientific Film Association, it was decided to form an International Scientific Film Association. A provisional constitution was agreed by the delegates from twenty-two countries, under which the Association will have a main meeting each year, but between these main meetings the affairs of the Association will be managed by a council comprising five officers and seven other members. The Council for the present year is : President, M. Korngold (Poland); Vice-Presidents. J. Maddison (Great Britain) and Prof. Pinto (Brazil); Hon. Secretary, M. Jean Painlévé (France); Hon. Treasurer, M. Sallaz (Switzerland); and one delegate each from Australia, Austria, Belgium, Canada, Czechoslovakia, Malaya and Mexico. The Association will be concerned with all aspects of scientific film matters. The exchange of information through the office of the Association (which will be established in Paris at an early date) will begin at once on scientific and technical films that are already available for exchange, on methods of appraisal, and on customs regulations on the exchange of films. Concurrently with each annual meeting of the Association, which will be held in different countries by invitation, there will be an examination of new scientific and technical films. The 1948 Congress is to be held in Great Britain in October; arrangements are being put in hand by the Scientific Film Association of Great Britain, 34 Soho Square, London, W.1.

\section{Archæological Work in Greece}

DURING the war years little archæological excavation was possible in Greece; but here and there minor discoveries were made, and these are summarized in the annual report of the Committes of the British School of Archæology at Athens. It appears in the Journal of Hellenic Studies, 64 (1944), and carries the story down to 1945. There are some illustrations, including a portion of a tholos tomb discovered near Knossos.

\section{University of London: Appointments}

THE following appointments in the University of London have been announced: Prof. Henry Barcroft, since 1935 Dunville professor of physiology in the Queen's University of Belfast, to the University chair of physiology tenable at St. Thomas's Hospital Medical School as from January 1, 1948 ; Dr. T. D. Day, to the University readership in pathology tenable at St. Thomas's Hospital Medical School; Dr. Russell Fraser, to the University readership in medicine tenable at the British Postgraduate Medical School; Dr. C. J. O. R. Morris, to the University readership in chemical pathology tenable at the London Hospital Medical College.

The title of professor emeritus of mining geology in the University has been conferred on Prof. W. R. Jones on his retirement from the chair of mining geology at the Imperial College of Science and Technology.

The degree of D.Sc. has been conferred on the following: Mr. Sachindranath Dasgupta (Imperial College of Science and Technology); Mr. Norman Davy; Mr. R. L. Knight (Wye College); Mr. W. S. Martin (Imperial College of Science and Technology); Prof. Claude Rimington (University professor of chemical pathology, University College Hospital Medical School); Mr. Yung Chow Wong (King's College).

\section{Announcements}

A JorNT conference of the Midland Branch and the X-ray Analysis Group of the Institute of Physics to discuss "The Structure and Physical Properties of Metals" will be held at Birmingham during November 20-21. Further particulars of the meeting, which is open free of charge to all who are interested, can be obtained from J. N. Kellar, honorary secretary of the X-ray Analysis Group, Crystallographic Laboratory, Cavendish Laboratory, Cambridge.

THE annual conference of the Agricultural Section of the Association of Scientific Workers will be held during November 8 and 9 at Gas Industry House, Hyde Park Corner, London. Sir John Fryer, secretary of the Agricultural Research Council, will address the first session at 3 p.m., which is open to all agricultural scientific workers.

Dr. Wriliam A. Hamor, of the Mellon Institute, Pittsburgh, has been appointed editor of the Chemical Monographs of the American Chemical Society. This series of reference volumes now numbers 105. 